\title{
PENGGUNAAN MODEL PEMBELAJARANBERMAIN PERAN (ROLE PLAYING) UNTUK MENINGKATKAN HASIL BELAJAR PKN PADA SISWA KELAS I SD NEGERI 168432 TEBING TINGGI
}

\author{
Dosma Udur \\ Surel: ibudosmaudur@gmail.com
}

\begin{abstract}
ABSTRAK
Tujuan dari penelitian ini adalah untuk meningkatkan hasil belajar PKN Kelas I SD Negeri 168432 kota Tebing Tinggi tahun pelajaran 2016/2017 melalui metode pembelajaran kooperatif Bermain Peran (Role Playing). Penelitian tindakan kelas an dilaksanakan sebanyak 2 siklus. Subjek penelitian adalah siswa kelas I SD Negeri 168432 kota Tebing Tinggi. Pelajaran dengan metode bermain peran pada materi pelajaran PKN di kelas I SD Negeri168432 kota Tebing Tinggi memiliki dampak positif dalam meningkatkan hasil belajar siswa yang ditandai dengan peningkatan ketuntasan belajar siswa dalam setiap siklus, yaitu siklus I (66\%), siklus II (87\%) dan dinyatakan berhasil. Selain itu sebagaimana dalam indikator penelitian ini dikatakan penelitian ini akan dikatakan berhasil jika persentase pengelolaan pelajaran mencapai $85 \%$, sementara pada akhir siklus II pengelolaan pelajaran sudah mencapai $88,1 \%$.
\end{abstract}

Kata Kunci: Bermain Peran, Hasil Belajar, PKN

\section{PENDAHULUAN}

Pada kenyataannya, PKn dianggap ilmu yang sukar dan sulit dipahami. PKn adalah pelajaran formal yang berupa sejarah masa lampau, perkembangan sosial budaya, perkembangan teknologi, tata cara hidup bersosial, serta peraturan kenegaraan. Begitu luasnya materi PKn menyebabkan anak sulit untuk diajak berfikir kritis dan kreatif dalam menyikapi masalah yang berbeda.

Sementara anak usia sekolah dasar tahap berfikir mereka masih belum formal, apa yang dianggap logis, jelas dan dapat dipelajari bagi orang dewasa, kadang-kadang merupakan hal yang tidak masuk akal dan membingungkan bagi siswa.
Akibatnya banyak siswa yang tidak memahami konsep PKn.

Dalam melaksankan tugas di lapangan peneliti sebagai guru kelas SD Negeri 168432 masih banyak menemui berbagai kendala. Masih banyak mata pelajaran yang belum sepenuhnya dikuasai siswa sesuai dengan standar kompetensi yang diharapkan, terutama dalam mata pelajaran PKn tentang Negara Kesatuan republik Indonesia (NKRI) dengan penguasaan materi masih rendah, hal ini dapat dilihat dari ratarata pencapaian nilai ketuntasan dengan tingkat ketuntasan $8 \%$. Dari jumlah 25 siswa hanya 10 siswa $40 \%$ yang memperoleh nilai $70 \mathrm{ke}$ atas. Sedangkan 20 siswa yang lain $60 \%$ mendapat nilai dibawah 70 . Untuk itu

Guru SD Negeri 168432 Tebing Tinggi 
perlu mendapat penanganan dan perhatian peneliti. Selain rendahnya prestasi belajar siswa, sikap masa bodoh siswa terhadap materi dalam pembelajaran diabaikan.

Menghadapi kenyataan tersebut di atas, penulis tertarik untuk mendalami dan melakukan tindakan-tindakan perbaikan pembelajaran PKN, melalui penelitian tindakan kelas. Khususnya materi Memahami Negara Kesatuan Republik Indonesia (NKRI) melalui penelitian tindakan kelas.

Berdasarkan latar belakanng dan identifikasai masalah di atas, rumusan masalah pada penelitian ini adalah apakah penggunaan metode pembelajaran bermain peran (role playing) dapat meningkatkan hasil belajar siswa kelas I SD Negeri 168432 Tebing Tinggi pada mata pelajaran PKn ?

Tujuan dari penelitian ini adalah untuk meningkatkan hasil belajar PKn melalui metode pembelajaran bermain peran pada siswa kelas I SD Negeri 168432 kota Tebing Tinggi tahun pelajaran 2016/2017.

Sedangkan manfaat penelitian ini adalah sebagai berikut :

a. Bagi siswa karena dapat meningkatkan hasil belajar PKn materi NKRI melalui metode pembelajaran bermain peran pada siswa kelas I SD Negeri 168432 kota Tebing Tinggi.

b. Bagi guru meningkatkan kualitas guru dalam melaksanakan tugas mengajar terutama dalam mengajar PKn.

c. Bagi sekolah sebagai masukan dalam upaya perbaikan pembelajaran sehingga dapat menunjang tercapainya kurikulum dan daya serap siswa seperti yang diharapkan.

Aktivitas siswa yang diamati dalam penelitian ini adalah sebagai berikut:

a. Mengajukan pertanyaan

b. Menjawab pertanyaan siswa maupun guru

c. Memberi saran

d. Mengemukakan pendapat

e. Menyelesaikan tugas kelompok

f. Mempresentasikan hasil kerja kelompok

Dalam penelitian ini hasil belajar pada pelajaran PKn materi Negara Kesatuan Republik Indonesia yang diukur melalui tes formatif dengan KKM 70. Bagi siswa yang nilainya kurang dari 70 diberi soal perbaikan dan bagi siswa yang nilainya 70 ke atas diberi soal pengayaan dalam bentuk pekerjaan rumah.

PKn bertujuan mengembangkan potensi individu warga negara, dengan demikian maka seorang guru PKn haruslah menjadi guru yang berkualitas dan profesional, sebab jika guru tidak berkualitas tentu tujuan PKn itu sendiri tidak tercapai. Melalui metode bermain peran siswa diajak untuk 
belajar memecahkan masalah pribadi, dengan bantuan kelompok sosial yang anggotanya teman- temannya sendiri.

Dengan kata lain model pembelajaran ini berupaya membantu individu melalui proses kelompok sosial. Melalui bermain peran, para siswa mencoba mengeksploitasi massalah-masalah hubungan antara manusia dengan cara memperagakannya. Hasilnya didiskusikan dalam kelas.

Tujuan dari penggunaan model bermain peran adalah sebagai berikut :

a. Untuk motivasi siswa.

b. Untuk menarik minat dan perhatian siswa.

c. Memberikan kesempatan kepada siswa untuk mengeksplorasi situasi dimana mereka mengalami emosi, perbedaan pendapat, dan permasalahan dalam lingkungan kehidupan social anak.

d. Menarik siswa untuk bertanya.

e. Mengembangkan kemampuan komunikasi siswa.

f. Melatih siswa untuk berperan aktif dalam kehidupan nyata.

Hal penting dalam model pembelajaran bermain peran adalah keterlibatan siswa untuk berpartisipasi dalam situasi atau masalah nyata serta adanya keinginan untuk mengatasi suatu masalah bersama. Pemahaman siswa dalam model bermain peran dapat memberikan contoh pada siswa dalam kehidupan sehari - hari untuk berperilaku sebagai berikut :

1. Menyayangi perasaan.

2. Menambah pengetahuan tentang sikap, nilai-nilai dan persepsinya.

3. Mengembangkan keterampilan dan sikapnya dalam memecahkan masalah.

4. Mengkaji pelajaran dengan berbagai cara.

Dengan menggunakan model pembelajaran Kooperatif bermain peran (Role Playing) siswa diharapkan dapat bekerjasama, saling membantu mengembangkan potensi diri secara optimal bagi kelompoknya dan belajar memperoleh dan memahami pengetahuan yang dibutuhkan secara langsung, serta melibatkan siswa aktif dalam mengembangkan pengetahuan, sikap, keterampilan dalam suasana belajar yang menyenangkan mereka, sehingga apa yang dipelajari lebih bermakna dan dipahami bagi diri setiap siswa.

\section{METODE PENELITIAN}

Penelitian ini bertempat di SD Negeri 168432 terletak di Jl. Rumah Sakit Umum Kelurahan Pasar Baru, Kecamatan Tebing Tinggi kota, Kota Tebing Tinggi.

Subyek penelitian adalah siswa-siswi Kelas I SD Negeri 168432 kota Tebing Tinggi Tahun Pelajaran 2016/2017 berjumlah 25 orang. 
Waktu penelitian ini dilaksanakan dari bulan Maret sampai dengan Mei 2017 dengan prosedur penelitian yang digunakan adalah penelitian tindakan kelas yang terdiri dari 2 siklus dengan menggunakan model penelitian tindakan dari Kemmis Mc Taggart (Arikunto, 2006:6) yaitu berbentuk spiral dari siklus yang satu ke siklus yang berikutnya. Setiap siklus meliputi planning (rencana), action (tindakan), observation (pengamatan), dan reflection (refleksi). Langkah pada siklus berikutnya adalah perncanaan yang sudah direvisi, tindakan, pengamatan, dan refleksi. Sebelum masuk pada siklus 1 dilakukan tindakan pendahuluan yang berupa identifikasi permasalahan.

Pada tahap implementasi pelaksanaan tindakan ini guru melakukan pelajaran di dalam kelas dengan menggunakan panduan perencanaan yang telah dibuat. Suasana masing-masing kelompok di kelas dikondisikan agar tidak terlalu formal, maksudnya siswa bebas mengemukakan pendapatnya tentang materi ajar sesuai dengan kompetensi dasar yang ingin dicapai. Siswa berinteraksi kepada guru secara langsung, bebas, sesuai kondisi nyata dan menyenangkan.

Instrumen dalam penelitian ini adalah tes hasil belajar yang dilaksanakan setiap akhir siklus. Tes berbentuk tes uraian yang bertujuan untuk mengetahui ketuntasan belajar siswa secara individual maupun secara klasikal. Disamping itu untuk mengetahui letak kesalahankesalahan yang dilakukan siswa sehingga dapat dilihat dimana kelemahannya, khususnya pada materi ajar yang belum tercapai.

Untuk memperkuat data yang dikumpulkan, maka juga digunakan observasi (pengamatan) yang dilakukan oleh teman sejawat untuk mengetahui dan merekam aktifitas guru dan siswa dalam proses belajar mengajar.

Pada penelitian ini menggunakan teknik analisis dekriptif kualitatif dengan tujuan untuk mengetahui pemahaman yang dicapai siswa, juga untuk memperoleh respon siswa terhadap kegiatan pelajaran serta aktivitas siswa selama proses pelajaran.

$$
\text { Pada penelitian ini }
$$
menggunakan teknik analisis dekriptif kualitatif, yaitu suatu metode penelitian yang bersifat menggambarkan kenyataan atau fakta sesuai dengan data yang diperoleh dengan tujuan untuk mengetahui pemahaman yang dicapai siswa, juga untuk memperoleh respon siswa terhadap kegiatan pelajaran serta aktivitas siswa selama proses pelajaran.

Penelitian ini dapat dikatakan berhasil dan tidak perlu dilanjutkan kepada siklus berikutnya apabila hasil dari tes siswa yang berjumlah 25 orang telah sesuai dengan KKM yang ditentukan yaitu 70 atau tingkat ketuntasan kelas diatas $85 \%$ dari 25 
siswa. Selain itu jika dilihat dari pengelolaan pelajaran, yaitu persentase pengelolaan pelajaran yaitu aktivitas guru dan aktivitas siswa di atas $85 \%$.

\section{HASIL DAN PEMBAHASAN}

Sebelum penelitian dilakukan, terlebih dahulu peneliti mengadakan survei pra siklus pada minggu sebelumnya.

Peneliti mengidentifikasi masalah melalui pengamatan proses belajar mengajar yakni rendahnya hasil belajar siswa pada kelas V SD Negeri 165737 Tebing Tinggi mata pelajaran PKN.
Kegiatan ini dilakukan dengan tujuan menyampaikan maksud mengadakan penelitian tindakan kelas dengan menerapkan metode bermain peran untuk meningkatkan aktivitas siswa dalam proses pembelajaran. Pada pengamatan dilakukan dengan menggunakan lembar observasi aktivitas siswa dan menggunakan penilaian hasil evaluasi melalui ulangan harian. Jumlah siswa yang lulus pada hasil evaluasi yang dilakukan adalah sebanyak 10 siswa memenuhi kriteria nilai KKM dari 25 siswa, yang ditunjukkan pada tabel berikut:

Tabel Nilai Tes Ulangan Harian Pra Siklus

\begin{tabular}{|c|c|c|c|c|c|c|c|c|c|}
\hline \multirow{2}{*}{ No. } & \multirow{2}{*}{$\begin{array}{l}\text { No Kode } \\
\text { Siswa }\end{array}$} & \multirow{2}{*}{ Nilai } & \multicolumn{2}{|c|}{ Keterangan } & \multirow{2}{*}{ No. } & \multirow{2}{*}{$\begin{array}{l}\text { No. Kode } \\
\text { Siswa }\end{array}$} & \multirow{2}{*}{ Nilai } & \multicolumn{2}{|c|}{ Keterangan } \\
\hline & & & $\mathrm{T}$ & TT & & & & $\mathrm{T}$ & TT \\
\hline 1 & 001 & 65 & $\sqrt{ }$ & & 14 & 014 & 60 & & $\sqrt{ }$ \\
\hline 2 & 002 & 60 & & $\sqrt{ }$ & 15 & 015 & 75 & $\sqrt{ }$ & \\
\hline 3 & 003 & 55 & & $\sqrt{ }$ & 16 & 016 & 50 & & $\sqrt{ }$ \\
\hline 4 & 004 & 55 & & $\sqrt{ }$ & 17 & 017 & 60 & & $\sqrt{ }$ \\
\hline 5 & 005 & 60 & & $\sqrt{ }$ & 18 & 018 & 80 & $\sqrt{ }$ & \\
\hline 6 & 006 & 60 & & $\sqrt{ }$ & 19 & 019 & 60 & & $\sqrt{ }$ \\
\hline 7 & 007 & 70 & $\sqrt{ }$ & & 20 & 020 & 70 & $\sqrt{ }$ & \\
\hline 8 & 008 & 50 & & $\sqrt{ }$ & 21 & 021 & 55 & & $\sqrt{ }$ \\
\hline 9 & 009 & 80 & $\sqrt{ }$ & & 22 & 022 & 60 & & $\sqrt{ }$ \\
\hline 10 & 010 & 50 & & $\sqrt{ }$ & 23 & 023 & 55 & & $\sqrt{ }$ \\
\hline 11 & 011 & 80 & $\sqrt{ }$ & & 24 & 024 & 80 & $\sqrt{ }$ & \\
\hline 12 & 012 & 65 & $\sqrt{ }$ & & 25 & 025 & 60 & & $\sqrt{ }$ \\
\hline 13 & 013 & 70 & $\sqrt{ }$ & & & & & & \\
\hline \multicolumn{2}{|c|}{ Jumlah } & 820 & 6 & 7 & \multicolumn{2}{|c|}{ Jumlah } & 755 & 4 & 8 \\
\hline
\end{tabular}


Dosma Udur: Penggunaan Model Pembelajaran ..

\begin{tabular}{|lc|}
\hline Jumlah Skor & $: 1575$ \\
Jumlah Skor Maksimal Ideal $: 2500$ \\
$\%$ Skor Tercapai & $: 63 \%$ \\
Jumlah siswa yang tuntas & $: 10$ \\
Klasikal & $:$ Belum Tuntas \\
\hline
\end{tabular}

Hasil tes ulangan harian pra siklus di atas dapat dilihat pada gambar grafik berikut:

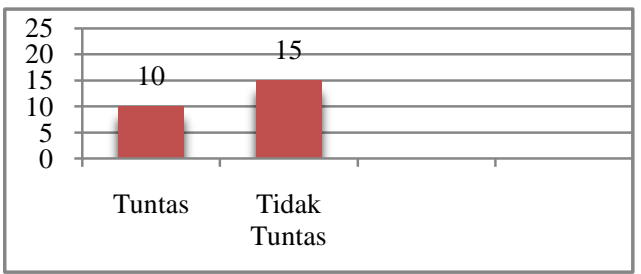

Gambar. Grafik Hasil Belajar Pra Siklus
Hasil temuan penelitian tindakan kelas dengan menggunakan model pembelajaran bermain peran pada siklus I yang dilaksanakan pada tanggal 12 Maret 2017 di kelas I SD Negeri 168432 Tebing Tinggi diperoleh hasil sebagai berikut:

Tabel Observasi Guru Pada Siklus I

\begin{tabular}{|c|c|c|c|c|}
\hline \multirow{2}{*}{ No } & \multirow{2}{*}{ Aspek yang diamati } & \multicolumn{2}{|c|}{ Penilaian } & \multirow{2}{*}{ Rata-rata } \\
\hline & & P1 & P2 & \\
\hline \multirow{3}{*}{ I } & $\begin{array}{l}\text { Pengamatan KBM } \\
\text { 1. Mendahuluan } \\
\text { 2. Menukan apersepsi } \\
\text { 3. Menghubaikan tujuan pembelajaran } \\
\text { 4. Mengatur siswa dalam kelompok-kelompok belajar }\end{array}$ & $\begin{array}{l}2 \\
3 \\
3 \\
2\end{array}$ & $\begin{array}{l}2 \\
3 \\
3 \\
2\end{array}$ & $\begin{array}{l}2 \\
3 \\
3 \\
2\end{array}$ \\
\hline & $\begin{array}{l}\text { Kegiatan inti } \\
\text { 1. Mempresentasikan langkah-langkah metode role } \\
\text { playing } \\
\text { 2. Membimbing siswa melakukan kegiatan } \\
\text { 3. Melatih keterampilan kooperatif } \\
\text { 4. Mengawasi setiap kelompok secara bergiliran } \\
\text { 5. Memberikan bantuan kepada kelompok yang } \\
\text { mengalami kesulitan }\end{array}$ & $\begin{array}{l}3 \\
3 \\
3 \\
3 \\
2\end{array}$ & $\begin{array}{l}3 \\
3 \\
3 \\
3 \\
2\end{array}$ & $\begin{array}{l}3 \\
3 \\
3 \\
3 \\
2\end{array}$ \\
\hline & $\begin{array}{l}\text { Penutup } \\
\text { 1. Membimbing siswa membuat rangkuman } \\
\text { 2. Memberikan evaluasi } \\
\text { 3. Memotivasi siswa }\end{array}$ & $\begin{array}{l}3 \\
3 \\
2\end{array}$ & $\begin{array}{l}3 \\
3 \\
2\end{array}$ & $\begin{array}{l}3 \\
3 \\
2\end{array}$ \\
\hline II & Pengelolaan Waktu & 2 & 2 & 2 \\
\hline III & $\begin{array}{l}\text { Antusiasme Kelas } \\
\text { 1. Antusias Siswa } \\
\text { 2. Antusias Guru }\end{array}$ & $\begin{array}{l}2 \\
3 \\
\end{array}$ & $\begin{array}{l}2 \\
3\end{array}$ & $\begin{array}{l}2 \\
3\end{array}$ \\
\hline & Jumlah & 39 & 39 & 39 \\
\hline
\end{tabular}


Keterangan : Nilai : Kriteria

$$
\begin{array}{ll}
1 & =\text { Tidak Baik } \\
2 & =\text { Cukup Baik }
\end{array}
$$

Berdasarkan tabel di atas aspek-aspek yang mendapatkan kriteria kurang baik adalah melakukan apersepsi, mengatur siswa dalam kelompok-kelompok belajar, memberikan bantuan kepada pasangan kelompok yang mengalami kesulitan, pengelolaan waktu, memotivasi siswa dan siswa antusias.
3 = Kurang Baik

4 = Baik

Kelima aspek yang mendapat nilai kurang baik di atas, merupakan suatu kelemahan yang terjadi pada siklus I dan akan dijadikan bahan kajian untuk refleksi dan revisi yang akan dilakukan pada siklus II. Hasil observasi berikutnya adalah aktivitas guru dan siswa seperti pada tabel berikut:

Tabel Hasil Observasi Aktivitas Siswa Pada Siklus I

\begin{tabular}{|c|l|c|c|}
\hline No & \multicolumn{1}{|c|}{ Aktivitas siswa yang diamati } & $\begin{array}{c}\text { Presentase } \\
\text { Maksimal }\end{array}$ & $\begin{array}{c}\text { Presentase } \\
\text { Perolehan }\end{array}$ \\
\hline 1 & Mendengarkan/ memperhatikan penjelasan guru & 10 & 6.3 \\
\hline 2 & Membaca buku & 10 & 6.0 \\
\hline 3 & Keantusiasan siswa mengikuti pelajaran & 10 & 5.5 \\
\hline 4 & $\begin{array}{l}\text { Siswa membentuk kelompok dengan tertib dan } \\
\text { melaksanakan kegiatan bermain peran/role } \\
\text { playing }\end{array}$ & 10 & 5.3 \\
\hline 5 & $\begin{array}{l}\text { Melakukan diskusi tentang materi pelajaran } \\
\text { dengan teman sekelompoknya }\end{array}$ & 10 & 5.5 \\
\hline 6 & $\begin{array}{l}\text { Siswa menuliskan dan mengerjakan Lembar Kerja } \\
\text { Siswa }\end{array}$ & 10 & 6.5 \\
\hline 7 & Menuliskan dan menyampaikan hasil diskusi & 10 & 5.7 \\
\hline 8 & $\begin{array}{l}\text { Mengajukan pendapat/ ide, bertanya atau } \\
\text { berkomentar kepada guru dan siswa }\end{array}$ & 10 & 5.0 \\
\hline 9 & Merangkum pembelajaran & 10 & 5.5 \\
\hline 10 & Mengerjakan tes evaluasi & 10 & 6.2 \\
\hline \multicolumn{2}{|c|}{ Persentase Aktivitas Siswa } & 57.5 \\
\hline
\end{tabular}

Keterangan : Nilai Persentase

$$
\begin{aligned}
& 86-100 \% \\
& 70-85 \% \\
& 1-69 \%
\end{aligned}
$$

Kriteria

Baik

Cukup

Kurang 
Hasil tes hasil belajar siswa

berikut:

pada siklus I dapat dilihat pada tabel

Tabel Distribusi Hasil Tes Ulangan Harian Siswa pada Siklus I

\begin{tabular}{|c|c|c|}
\hline No & Uraian & Hasil Siklus I \\
\hline 1 & Nilai rata-rata tes ulangan harian & 65,8 \\
2 & Jumlah siswa yang tuntas belajar & 17 \\
3 & Persentase ketuntasan belajar & 68 \\
\hline
\end{tabular}

Keterangan:

Jumlah siswa yang tuntas $\quad: 17$

Jumlah siswa yang belum tuntas : 8

Klasikal

: Belum tuntas

Hasil tes ulangan harian siklus I dapat dilihat pada grafik berikut :

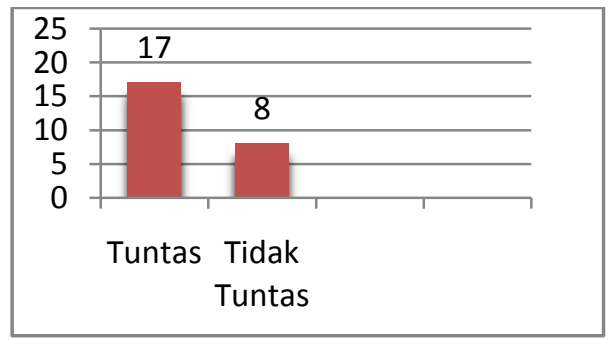

\section{Gambar. Grafik Hasil Belajar}

Siklus I

Dapat dijelaskan hasil belajar siswa pada siklus I bahwa dengan menerapkan metode pembelajaran bermain peran pada materi pelajaran diperoleh nilai rata-rata hasil belajar siswa adalah 65,8 dan ketuntasan belajar mencapai $68 \%$ atau ada 17 siswa dari 25 siswa sudah tuntas belajar. Hasil tersebut menunjukkan bahwa pada siklus pertama secara klasikal siswa belum tuntas belajar, karena siswa yang memperoleh nilai $\geq 70$ hanya sebesar $68 \%$ lebih kecil dari persentase ketuntasan yang dikehendaki yaitu sebesar $85 \%$. Namun dibandingkan dengan siklus sebelumnya, terjadi peningkatan hasil belajar siswa. Maka dari itu, dilanjutkan ke siklus II.

Pelaksanaan kegiatan belajar mengajar untuk siklus II dilaksanakan pada tanggal 5 April 2017 dengan jumlah siswa 25 siswa. Dalam hal ini peneliti bertindak sebagai guru. Adapun proses belajar mengajar mengacu pada rencana pelajaran dengan memperhatikan revisi pada siklus I, sehingga kesalahan atau kekurangan pada siklus I tidak terulang lagi pada siklus II. Pada akhir proses belajar mengajar siswa diberi tes ulangan harian II. Instrumen yang digunakan adalah tes ulangan harian II. Adapun data hasil penelitian pada siklus II adalah sebagai berikut : 
Tabel Observasi Guru Pada Siklus II

\begin{tabular}{|c|c|c|c|c|}
\hline \multirow{2}{*}{ No } & \multirow{2}{*}{ Aspek yang diamati } & \multicolumn{2}{|c|}{ Penilaian } & \multirow{2}{*}{ Rata-rata } \\
\hline & & $\mathrm{P} 1$ & P2 & \\
\hline \multirow{3}{*}{ I } & $\begin{array}{l}\text { Pengamatan KBM } \\
\text { Pendahuluan } \\
\text { 1. Melakukan apersepsi } \\
\text { 2. Menyampaikan tujuan pembelajaran } \\
\text { 3. Menghubungkan dengan pelajaran sebelumnya } \\
\text { 4. Mengatur siswa dalam kelompok-kelompok } \\
\text { belajar }\end{array}$ & $\begin{array}{l}3 \\
3 \\
3 \\
3\end{array}$ & $\begin{array}{l}3 \\
3 \\
3 \\
3\end{array}$ & $\begin{array}{l}3 \\
3 \\
3 \\
3\end{array}$ \\
\hline & $\begin{array}{l}\text { Kegiatan inti } \\
\text { 1. Mempresentasikan langkah-langkah metode } \\
\text { pembelajaran role playing } \\
\text { 2. Membimbing siswa melakukan kegiatan } \\
\text { 3. Melatih keterampilan kooperatif } \\
\text { 4. Mengawasi setiap kelompok secara bergiliran } \\
\text { 5. Memberikan bantuan kepada kelompok yang } \\
\text { mengalami kesulitan }\end{array}$ & $\begin{array}{l}3 \\
3 \\
3 \\
3 \\
3\end{array}$ & $\begin{array}{l}3 \\
3 \\
3 \\
3 \\
3\end{array}$ & $\begin{array}{l}3 \\
3 \\
3 \\
3 \\
3\end{array}$ \\
\hline & $\begin{array}{l}\text { Penutup } \\
\text { 1. Membimbing siswa membuat rangkuman } \\
\text { 2. Memberikan evaluasi } \\
\text { 3. Memotivasi siswa }\end{array}$ & $\begin{array}{l}3 \\
3 \\
3\end{array}$ & $\begin{array}{l}3 \\
3 \\
3\end{array}$ & $\begin{array}{l}3 \\
3 \\
3\end{array}$ \\
\hline II & Pengelolaan Waktu & 3 & 3 & 3 \\
\hline III & $\begin{array}{l}\text { Antusiasme Kelas } \\
\text { 1. Antusias Siswa } \\
\text { 2. Antusias Guru }\end{array}$ & $\begin{array}{l}3 \\
3\end{array}$ & $\begin{array}{l}3 \\
3\end{array}$ & $\begin{array}{l}3 \\
3\end{array}$ \\
\hline & $\begin{array}{ll}\text { Jumlah } \\
\end{array}$ & 45 & 45 & 45 \\
\hline
\end{tabular}

Keterangan : Nilai Kriteria

$$
\begin{aligned}
& 1=\text { Tidak Baik } \\
& 2=\text { Kurang Baik } \\
& 3=\text { Cukup Baik } \\
& 4=\text { Baik }
\end{aligned}
$$

Dari tabel di atas, dapat dilihat aspek-aspek yang diamati pada siklus II yang dilaksanakan oleh guru dengan menerapkan metode pembelajaran bermain peran mendapatkan penilaian baik dari pengamat adalah mempresentasikan langkah-langkah metode pembelajaran bermain perandan membimbing siswa melakukan kegiatan. Penyempurnaan aspekaspek diatas dalam menerapkan metode pembelajaran bermain peran dengan meninjau ulang telah berhasil semaksimal mungkin.

Hasil observasi pada kegiatan siswa dapat dilihat pada tabel berikut: 
Dosma Udur: Penggunaan Model Pembelajaran ..

Tabel Hasil Observasi Kegiatan Siswa Pada Siklus II

\begin{tabular}{|c|l|c|c|}
\hline No & \multicolumn{1}{|c|}{ Aktivitas siswa yang diamati } & $\begin{array}{c}\text { Presentase } \\
\text { Maksimal }\end{array}$ & $\begin{array}{c}\text { Presentase } \\
\text { Perolehan }\end{array}$ \\
\hline 1 & $\begin{array}{l}\text { Mendengarkan/ memperhatikan penjelasan } \\
\text { guru }\end{array}$ & 10 & 8.5 \\
\hline 2 & Membaca buku & 10 & 8.0 \\
\hline 3 & Keantusiasan siswa mengikuti pelajaran & 10 & 8.5 \\
\hline 4 & Siswa membentuk kelompok dengan tertib & 10 & 8.6 \\
\hline 5 & $\begin{array}{l}\text { Melakukan diskusi tentang materi pelajaran } \\
\text { dengan teman sekelompoknya }\end{array}$ & 10 & 8.5 \\
\hline 6 & $\begin{array}{l}\text { Siswa menuliskan dan mengerjakan Lembar } \\
\text { Kerja Siswa }\end{array}$ & 10 & 8.0 \\
\hline 7 & $\begin{array}{l}\text { Menuliskan dan menyampaikan hasil } \\
\text { diskusi }\end{array}$ & 10 & 8.0 \\
\hline 8 & $\begin{array}{l}\text { Mengajukan pendapat/ ide, bertanya atau } \\
\text { berkomentar kepada guru dan siswa }\end{array}$ & 10 & 8.0 \\
\hline 9 & Merangkum pembelajaran & 10 & 8.5 \\
\hline 10 & Mengerjakan tes evaluasi & 10 & 8.8 \\
\hline \multicolumn{2}{|c|}{ Persentase Aktivitas Siswa } & 100 & 86,6 \\
\hline
\end{tabular}

Keterangan : Nilai Persentase

$$
\begin{aligned}
& 86-100 \% \\
& 70-85 \%
\end{aligned}
$$$$
1-69 \%
$$

Dari tabel di atas dapat dilihat secara garis besar kegiatan belajar mengajar dengan metode pembelajaran inkuiri dilaksanakan sudah sangat baik. Hal ini dapat disimpulkan bahwa hasil pengamatan terhadap aktivitas siswa dalam
Kriteria

Baik

Cukup Baik

Kurang

pembelajaran mengalami peningkatan dibanding pada siklus I.

Hasil belajar siswa pembelajaran PKn melalui tes ulangan harian dapat dilihat pada tabel berikut :

\section{Tabel Distribusi Hasil Tes Ulangan Harian Siswa pada Siklus II}

\begin{tabular}{|c|l|c|}
\hline No & \multicolumn{1}{|c|}{ Uraian } & Hasil Siklus II \\
\hline 1 & Nilai rata-rata tes Ulangan harian & 76 \\
2 & Jumlah siswa yang tuntas belajar & 22 \\
3 & Persentase ketuntasan belajar & 88 \\
\hline
\end{tabular}


Keterangan:

Jumlah siswa yang tuntas

Jumlah siswa yang belum tuntas

Klasikal

Berdasarkan tabel di atas diperoleh nilai rata-rata tes Ulangan Harian sebesar 76 dan dari 25 siswa yang telah tuntas sebanyak 22 siswa dan 3 siswa belum mencapai ketuntasan belajar. Maka secara klasikal ketuntasan belajar yang telah tercapai sebesar 88\% (termasuk kategori tuntas). Hasil pada siklus II ini mengalami peningkatan lebih baik dari siklus I. Adanya peningkatan hasil belajar pada siklus II dapat dilihat pada grafik berikut:

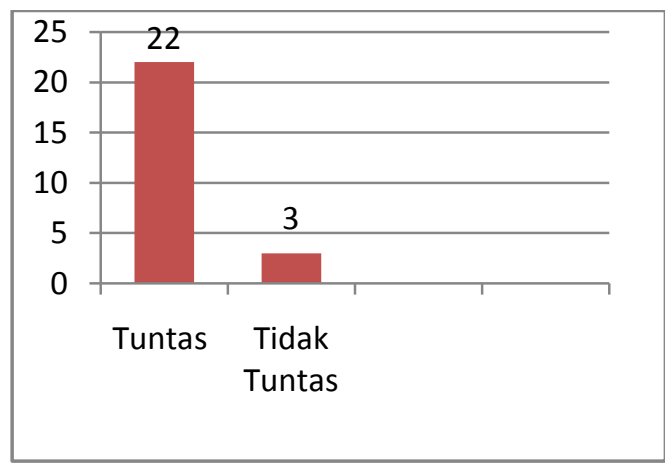

\section{Gambar. Grafik Tes Hasil Belajar Siklus II}

\section{Pembahasan}

Dari hasil penelitian yang diperoleh melalui kegiatan belajar mengajar yang dilaksanakan sebanyak 2 siklus yang dilakukan
$: 22$

$: 3$

: Tuntas

dengan menggunakan tes dan observasi aktivitas siswa dan guru dalam pembelajaran maka dapat dinyatakan bahwa model pembelajaran bermain peran (role playing) dalam mata pelajaran $\mathrm{PKn}$ pada materi NKRI mengalami peningkatan, hal ini terlihat dari hasil belajar siswa yang tuntas sebesar $68 \%$ pada siklus I meningkat menjadi $88 \%$ pada siklus II.

Hal ini dimungkinkan karena model pembelajaran bermain peran membuat siswa menjadi aktif dalam kegiatan belajar khususnya di kelas I SD yang memang masih mengutamakan aktivitas bermain dalam kegiatannya.

Dari hasil tes ini dapat dilihat bahwa hasil belajar dengan menggunakan metode pembelajaran bermain peran telah mampu meningkatkan hasil belajar pada mata pelajaran PKN sesuai dengan indikator yang telah ditentukan sehingga tidak perlu lagi dilanjutkan pada siklus berikutnya dan dikatakan berhasil. Gambaran peningkatan hasil belajar yang diperoleh setelah melakukan penelitian dengan menggunakan metode pembelajaran inkuiri terlihat pada tabel berikut: 


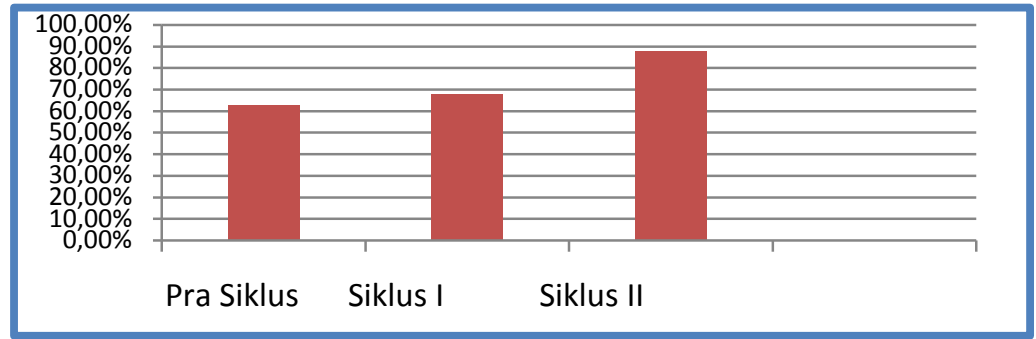

\section{Gambar. Grafik Peningkatan Hasil Belajar Siswa}

\section{SIMPULAN}

Dari hasil temuan penelitian tentang hasil belajar siswa dengan metode pembelajaran bermain perandi kelas I SD Negeri 168432 Tebing Tinggi tahun pelajaran 2016/2017 berdampak positif dalam meningkatkan hasil belajar siswa. Hal tersebut dapat dilihat dari peningkatan persentase ketuntasan belajar siswa pada pra siklus (63\%), siklus I (68\%), dan siklus II (88\%).

Aktivitas siswa dalam proses pembelajaran dengan menggunakan model pembelajaran bermain peran juga berjalan maksimal

\section{DAFTAR RUJUKAN}

Andayani, dkk. 2010. Pemantapan Kemampuan Profesional. Jakarta: Universitas Terbuka.

Arikunto, S. 2002. Penelitian Tindakan Kelas. Jakarta: PT Bumi Aksara

Chairani Lubis. 2011. Meningkatkan Kemampuan Berbicara Siswa Pada Pelajaran Bahasa Indonesia Dengan
Menggunakan

Metode

Bermain Peran Bagi Siswa Kelas V SD Swasta Cendekia T. A 2011/ 2012.(Penelitian Tindakan Kelas). Medan: Universitas Negeri Medan

Depdiknas. 2007. Pedoman Pengembangan Silabus dan Model Pembelajaran. Buku IV. Jakarta: Dikmenum Depdiknas.

Depdiknas. 2005. UU Sisdiknas No. 20 Tahun 2003. Jakarta: Depdiknas.

Dra. Dyah Sriwilujeng. Buku PKn untuk SD Kelas V. Jakarta: Exis.

Gatot, Muhsetyo, Drs. M.Sc, dkk. 2007. Pembelajaran PKN. Jakarta: UniversitasTerbuka.

Hamalik, Omar. 2001. Belajar dan Pembelajaran. Jakarta: Rineka Cipta

Martati, Badruli. 2010. Metodelogi Pembelajaran Pendidikan Kewarganegaraan. Bandung: Genesindo. 
Muhibbin Syah. 2005. Psikologi Pembelajaran. Jakarta: PT Raja Grafindo Persada.

Rumisih. 2012. Upaya Meningkatkan Hasil Belajar Pada Mata Pelajaran PKn Melalui Metode Bermain Peran Dengan Model Pembelajaran Cooperative Learning Kelas $V$ Sd Negeri Sumber Mulyo O1 tahun 2012/2013. (Penelitian Tindakan Kelas).
Surabaya: Universitas Terbuka

Slavin, Robert E. 2005. Pembelajaran Kooperatif. Alih bahasa: Mohamad Nur, dkk. Surabaya: Pusat Sains dan Matematika sekolah UNESA.

Sudjana, Nana. 2010. Dasar-Dasar Proses Belajar Mengajar. Bandung: Sinar Baru Algesindo. 